Biol. Stud. 2020: 14(4); 23-34 • DOI: https://doi.org/10.30970/sbi.1404.640

www.http://publications.Inu.edu.ua/journals/index.php/biology

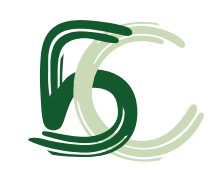

UDC: 502

\title{
ANALYSIS OF SOLID WASTE LANDFILLS VEGETATION COVER OF KHARKIV REGION
}

\author{
Ya. Yu. Dementieieva®*, S. V. Aseeva ${ }^{\circledR}$ L. Yu. Andrusenko®, A. B. Chaplygina \\ H. S. Skovoroda Kharkiv National Pedagogical University \\ 29, Alchevskikh St., Kharkiv 61002, Ukraine \\ *Corresponding author e-mail: dementeeva.y@gmail.com
}

Dementieieva Ya.Yu., Aseeva S.V., Andrusenko L.Yu, Chaplygina A.B. Analysis of solid waste landfills vegetation cover of Kharkiv region. Studia Biologica, 2020: 14(4); 23-34 • DOI: https:// doi.org/10.30970/sbi.1404.640

Background. Determination of plant species diversity in the areas of solid waste landfills (hereinafter "landfills") was carried out in order to identify patterns of vegetation cover and give an ecological assessment of the technocenosis. Plant species diversity was definedon the territories of Derhachiv and Rohan landfills in the city of Kharkiv.

Materials and Methods. The method of linear routes and trial areas was used to determine the number of species. The degree of coverage was measured by the Drude method. The degree of similarity was determined by calculating the Jacquard coefficient. Plants were systematized by species, life forms, life expectancy, types of cenomorphs.

Results and Discussion. 117 species have been recorded at Kharkiv landfills in total. At Rohan landfill and in the adjacent territories the vegetation cover is represented by 92 species, at Derhachiv landfill - by 93 species. Because of the uneven distribution of vegetation in the territories, areas of landfills were identified according to the specifics of vegetation cover ( 4 for Derhachiv and 3 for Rohan landfills). The most pronounced species diversity of plants at Derhachiv landfill is in the zone of natural landscape (44.0\%), at Rohan landfill - in the zone of ruderal landscape (38.4 \%). The obtained data were classified by plant species composition and the conditions of their existence. Herbaceous plants of Derhachiv and Rohan llandfills are dominant in terms of life forms $-83.8 \%$ and $85.8 \%$, respectively. Perennial plants predominate in terms of life expectancy $-53.8 \%$ and $52.2 \%$, respectively. By their practical use, landfill plants include medicinal (18.6\%), food (11.1\%), and honey (10.8\%) ones; phytomeliorant plants constitute the smallest part $-2.2 \%$. The Drude method was used to determine the degree of coverage. The dominant families at both landfills are Asteraceae $(24.6 \%)$ and Poaceae (13\%). Jacquard similarity coefficients ranged from 0.18 in the least similar

(C) 2020 Yа. Yu. Dementieieva et al.; Published by the Ivan Franko National University of Lviv on behalf оf Біологічні Студії / Studia Biologica. This is an Open Access article distributed under the terms of the Creative Commons Attribution License (http://www.budapestopenaccessinitiative.org and Creative Commons Attribution 4.0 License), which permits unrestricted reuse, distribution, and reproduction in any medium, provided the original work is properly cited.

ISSN 1996-4536 (print) • ISSN 2311-0783 (on-line) • Біологічні Студії / Studia Biologica • 2020 • Том 14/№ 4 • С. 23-34 
zones to 0.75 in similar zones. Cj calculated for two landfills equals 0.11 . The plants were systematized by cenomorphic affiliation. The leading type of cenomorph for the flora of landfills is ruderal species $(\mathrm{Ru})$; a significant share is occupied by forest plants (Sil), meadow (Pr) and steppe (St) plant species.

Conclusions. Solid waste landfill sites are characterized by a high degree of transformation, which is clearly manifested in the vegetation formation patterns. The significant difference between the vegetation cover of landfill areas $(C j=0.11)$ indicates a low degree of similarity of species diversity due to the specifics of technogenesis of the studied ecosystems, historical landscape and preconditions for the formation of vegetation. Natural grass cover on the landfills is replaced by ruderal and shrub cover, which indicates harsh living conditions for cultivated plants and succession processes. There are three main patterns of the formarion of vegetation cover in the landfills: as a result of severe disturbances, indigenous plants are replaced by ruderants in the process of succession, while uncharacteristic species are introduced by biotic and abiotic factors.

Keywords: vegetation cover, Derhachiv landfill, Rohan landfill, transformed landscapes, cenomorphic affiliation

\section{INTRODUCTION}

The number of man-made landscapes is growing rapidly, the areas occupied by solid waste (hereinafter "landfills"), which have a negative impact on the state of environmental components, including vegetation, need special attention.

The literature widely elucidates the possibilities of monitoring various components of the natural environment of landfills $[6,7,19]$, which allows to respond in advance to the transformation of the natural environment, given the rapid response of plants as bioindicators. Numerous research works considered vegetation coverage peculiarities of landfills [3], its phytomeliorative properties [15, 17, 18, 27], migration of plant species and formation of plant communities in landfills [9, 16, 24], as well as accumulation of pollutant abiotic components of the natural environment by plants and fungi in the territories of the landfills [14, 20, 25].

The aim of this work was to study the species diversity of flora, analyze the functions and properties of different groups of plants at Rohan and Derhachiv landfills in Kharkiv, and provide an ecological assessment of the state of technogenically transformed landscapes.

\section{MATERIAL AND METHODS}

The study of the vegetation cover of the landfills was conducted during the period of active vegetation (May-July 2020) on the territory of Kharkiv landfill sites (see Figure).

Rohan landfill is located on the southern border of Kharkiv. According to the geobotanical zoning, this area is located in the forest-steppe zone, in the valley of the Studenok River. The mesorelief of the landfill is represented by a beam, which is a remnant of a former tributary of the Studenok River, that indicates a small depth of groundwater. The landfill exhausted its functional significance in 1995, but it is still used. For more than two decades, succession processes have been taking place on the territory and an ecosystem with a specific flora is being formed there.

Derhachiv landfill is located $15 \mathrm{~km}$ north of the city of Kharkiv in the valley of the river Lopan, on its left bank. The landfill is divided into separate functional zones - a new

ISSN 1996-4536 (print) • ISSN 2311-0783 (on-line) • Біологічні Студії / Studia Biologica • 2020 • Том 14/№ 4 • С. 23-34 
active landfill and an old one, reclaimed 20 years ago. The former landfill was laid 20 years ago and is now subject to backfilling and compaction for further reclamation [11]. The genesis of changes in the two studied landfills has some differences, primarily in the formation of flora.

Landfill vegetation cover was studied by method of geobotanical research. The main task was to identify general geobotanical characteristics of the territory and to determine the basic patterns of plant distribution relative to the landfill.

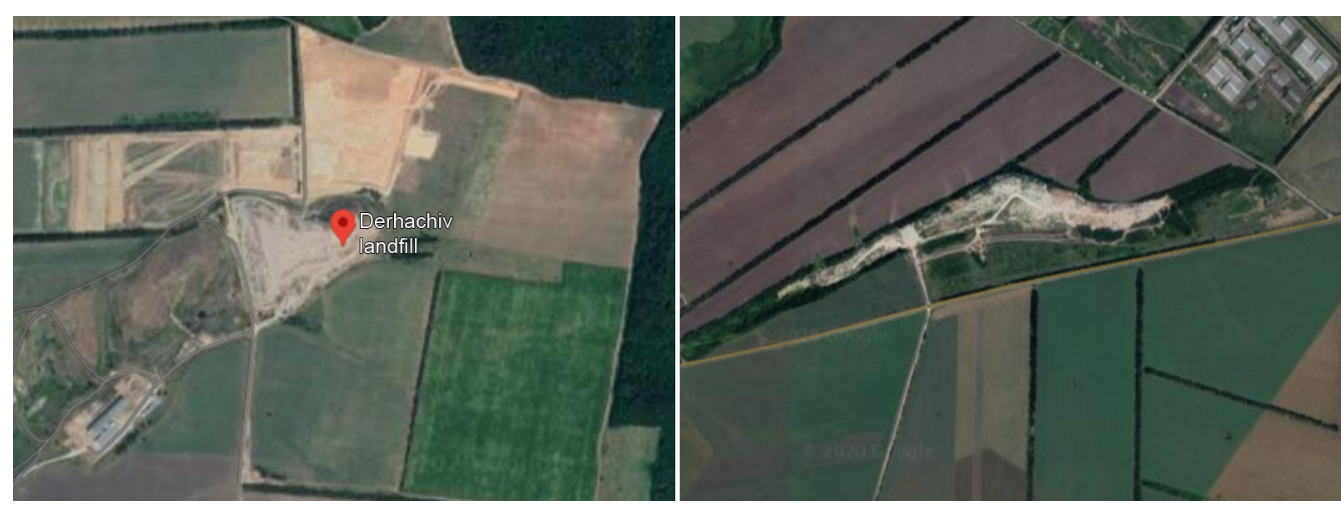

Derhachiv and Rohan landfills

Дергачівський і Роганський полігони ТПВ

The area with vegetation cover near the SW landfill and on its territory was covered by linear routes method. The method of trial areas $(10 \times 10)$ was used for studying the floristic composition and determining the conditions of vegetation existence. According to the results of the study, a list of flora species was compiled with the subsequent determination of dominant representatives and the construction of associations by determinant [12].

Drude's method (1913) was used for quantitative counting of plants [2]. After taking into account the qualitative and quantitative composition of the vegetation cover, the dominant plant species were identified [2], coenomorphs according to $\mathrm{O}$. Belgard were identified according to $\mathrm{V}$. Tarasov [23]. To compare the floristic similarity of the studied areas, the floristic similarity coefficient of Jacquard was used [8]. To characterize the degree of succession, the types of cenomorphs for all species represented at Rohan and Derhachiv landfills were determined [23].

\section{RESULTS AND DISCUSSION}

It was found that the vegetation cover of Rohan landfill and the adjacent territories includes at least 92 species of higher vascular plants belonging to 34 families. 93 species belonging to 29 families were recorded at Derhachiv landfill. The leading families at both landfills were the families Asteraceae and Poaceae (Table 1).

Analysis of life forms (according to Serebryakov) revealed the following: the vegetation cover of landfills includes herbaceous plants, trees, shrubberies, bushes and woody vines. The plants were grouped by life expectancy into perennial, annual and biennial species using the common method [21] (Table 2).

ISSN 1996-4536 (print) • ISSN 2311-0783 (on-line) • Біологічні Студії / Studia Biologica • 2020 • Том 14/№ 4 • С. 23-34 
Table 1. Systematic composition of vegetation of Rohan and Derhachiv landfills, \%

Таблиця 1. Систематичний склад рослинного покриву полігонів твердих побутових відходів, \%

\begin{tabular}{|c|c|c|c|c|c|}
\hline \multicolumn{6}{|c|}{ Rohan landfill } \\
\hline Asteraceae & $20.70 \%$ & Lamiaceae & $3.27 \%$ & Boraginaceae & $1.04 \%$ \\
\hline Poaceae & $13.00 \%$ & Salicaceae & $3.16 \%$ & Caryophyllaceae & $1.10 \%$ \\
\hline Fabaceae & $7.00 \%$ & Euphorbiaceae & $2.18 \%$ & Fagaceae & $1.10 \%$ \\
\hline Brassicaceae & $6.50 \%$ & Violaceae & $2.09 \%$ & Ranunculaceae & $1.10 \%$ \\
\hline Polygonaceae & $4.41 \%$ & Rosaceae & $2.09 \%$ & Asparagaceae & $1.10 \%$ \\
\hline Amaranthaceae & $3.38 \%$ & Rubiaceae & $2.81 \%$ & Cornaceae & $1.10 \%$ \\
\hline Apiaceae & $3.31 \%$ & Plantaginaceae & $2.10 \%$ & Oleaceae & $1.10 \%$ \\
\hline Sapindaceae & $3.35 \%$ & Caprifoliaceae & $1.00 \%$ & Scrophulariaceae & $1.10 \%$ \\
\hline Papaveraceae & $3.30 \%$ & Convolvulaceae & $1.01 \%$ & Ulmaceae & $1.10 \%$ \\
\hline Balsaminaceae & $1.10 \%$ & Malvaceae & $1.10 \%$ & Urticaceae & $0 \%$ \\
\hline Vitaceae & $1.10 \%$ & Onagraceae & $1.10 \%$ & Betulaceae & $0 \%$ \\
\hline Adoxaceae & $1.10 \%$ & Cyperaceae & $0 \%$ & Solanaceae & $0 \%$ \\
\hline \multicolumn{6}{|c|}{ Derhachiv landfill } \\
\hline Asteraceae & $24.60 \%$ & Salicaceae & $0 \%$ & Fagaceae & $1.10 \%$ \\
\hline Poaceae & $12.80 \%$ & Euphorbiaceae & $2.20 \%$ & Ranunculaceae & $1.10 \%$ \\
\hline Fabaceae & $5.30 \%$ & Violaceae & $1.10 \%$ & Asparagaceae & $0 \%$ \\
\hline Brassicaceae & $6.40 \%$ & Rosaceae & $7.40 \%$ & Cornaceae & $0 \%$ \\
\hline Polygonaceae & $4.30 \%$ & Rubiaceae & $1.10 \%$ & Oleaceae & $2.20 \%$ \\
\hline Amaranthaceae & $3.20 \%$ & Plantaginaceae & $2.20 \%$ & Scrophulariaceae & $1.10 \%$ \\
\hline Apiaceae & $3.20 \%$ & Caprifoliaceae & $1.10 \%$ & Ulmaceae & $1.10 \%$ \\
\hline Sapindaceae & $4.30 \%$ & Convolvulaceae & $2.20 \%$ & Balsaminaceae & $0 \%$ \\
\hline Papaveraceae & $1.00 \%$ & Boraginaceae & $1.10 \%$ & Vitaceae & $0 \%$ \\
\hline Lamiaceae & $3.20 \%$ & Caryophyllaceae & $1.10 \%$ & Adoxaceae & $1.10 \%$ \\
\hline Malvaceae & $0 \%$ & Betulaceae & $1.10 \%$ & Cyperáceae & $1.10 \%$ \\
\hline Onagraceae & $0 \%$ & Solanaceae & $1.10 \%$ & Urticaceae & $1.10 \%$ \\
\hline
\end{tabular}

Table 2. Distribution of vegetation by life forms and life expectancy

Таблиця 2. Розподіл рослинного покриву за життєвими формами і тривалістю життя

\begin{tabular}{lcccc|c}
\hline \multirow{2}{*}{ Landfill } & \multicolumn{5}{c}{ Life form type, \% } \\
& Herbaceous plants & Trees & Shrubs & Bushes & Wooden vines \\
\hline Rohan landfill & 85.8 & 9.8 & 2.2 & 1.1 & 1,1 \\
Derhachiv landfill & 83.8 & 9.7 & 1.1 & 5.3 & 0 \\
\hline \multicolumn{1}{c}{ Landfill } & Perennials & Lifetime & Biennials & Annuals \\
\hline Rohan landfill & 52.2 & 14.1 & 32.2 \\
Derhachiv landfill & 53.8 & 12.9 & 33.3 \\
\hline
\end{tabular}

ISSN 1996-4536 (print) • ISSN 2311-0783 (on-line) • Біологічні Студії / Studia Biologica • 2020 • Том 14/№ 4 • С. 23-34 
In the landfills, herbaceous perennials dominated, which indicates secondary succession processes in the formation of secondary vegetation on the transformed landscapes. The distribution of annual plant species indicates the primary formation of flora in the affected areas.

It was found that the vegetation cover is distributed unevenly on the territories of the landfills, therefore zoning of territories was carried out. Landfills in Kharkiv are characterized by a sharp dismemberment and a high degree of technogenic transformation of landscapes, have their own clearly separated perimeter of the territory where waste is stored (operating landfill, hereinafter OL), active zone of unloading and compaction of waste, which is constantly changing in the process of waste accumulation (the epicenter of landfill, hereinafter EL). Areas that do not meet the standards over time and exhaust their acceptance function are subject to reclamation (reclaimed landfill, hereinafter $R L$ ). The areas adjacent to the landfills are characterized by linearly elongated forms of the landscape (dirt roads) directly adjacent to the landfill site on the one side and ruderal vegetation on the other, and form the ruderal landscape $(R)$. Occasionally, there are small areas with relatively natural landscape features where grassy (NLG) or woody (NLW) vegetation predominantes.

Analysis of vegetation on the territory of Rohan and Derhachiv landfills revealed a certain difference in the species diversity of plants at landfills in accordance with the zoning of the territory (Table 3).

The most pronounced species diversity of vegetation was found at Derhachiv landfill in the NLW zone (44.0 \%), and at Rohan landfill - in the R zone (38.5\%). Asteraceae and Caprifoliaceae are the families whose representatives dominate the flora at both landfills. The heterogeneity of vegetation is obvious, which indicates the high level of transformation of active waste unloading areas - the impact of heavy machinery and waste. The dismemberment of the territory also sharply limits the species diversity in the OL and EL zones, where there is no vegetation. The area of active waste disposal $(\mathrm{OL})$ is depleted of vegetation; similar tendencies occur along the perimeter of the landfill, where ruderal and semi-natural complexes are formed, which are dominated by numerous species of weeds and synanthropic plants. Asteraceae (I rank), Caprifoliaceae (II rank) and Brassicaceae (III rank) occupy the leading place among families. Representatives of other families are found in different areas with different frequency. Agropyron repens (L.) Gould, 1947), Erigeron annuus (L.) Pers., 1807), Lactuca serriola (L., 1756) and Acernegundo (L., 1753), Ulmus sp. (L.) dominate the vegetation in the NLW zone. Ruderal and other weed-field plants predominate in the $\mathrm{R}$ area, which is due to their ability to grow in clogged areas with high humidity. There is a clear tendency of substitution of annuals and biennials dominating in the areas under the impact of heavy machinery and active unloading (OL, EL, R) with perennial species in the "older" areas, which is the evidence of the formation of secondary successions and stable phytocenoses.

The analysis of vegetation cover showed that the greatest diversity of species was formed at Derhachiv landfill in the natural landscape area. At the same time, there is a tendency to suppress ruderal vegetation by aboriginal species, which indicates the potential for landscape restoration. The zone of ruderal landscape is dominated by ruderal vegetation, which indicates the primary succession processes. At the reclaimed landfill, the plants adapted to the drier conditions of the areas under anthropogenic transformation.

A comparison of vegetation cover within Rohan and Derhachiv landfills and between these two landfills was made and the significance of the difftrence was determined using Jacquard similarity coefficient Cj (Table 4).

ISSN 1996-4536 (print) • ISSN 2311-0783 (on-line) • Біологічні Студії / Studia Biologica • 2020 • Том 14/№ 4 • С. 23-34 
Table 3. Species diversity of vegetation on the territory of Kharkiv landfills

Таблиця 3. Видове різноманіття рослинного покриву полігонів твердих побутових відходів Харківщини

\begin{tabular}{|c|c|c|c|c|c|c|c|c|}
\hline \multirow{3}{*}{$\begin{array}{l}\text { Ranking by sum } \\
\text { of species in all } \\
\text { territories }\end{array}$} & \multirow{3}{*}{ Family } & \multicolumn{3}{|c|}{ Rohan landfills } & \multicolumn{4}{|c|}{ Derhachiv landfills } \\
\hline & & \multicolumn{7}{|c|}{ Number of species in the family } \\
\hline & & NLG & NLW & $\mathrm{R}$ & NLG & $\mathrm{R}$ & $\mathrm{OL}$ & $\mathrm{RL}$ \\
\hline VIII & Euphorbiaceae & 2 & 2 & 1 & 2 & - & - & 2 \\
\hline$X V$ & Violaceae & 1 & 1 & 1 & 1 & - & - & - \\
\hline I & Asteraceae & 11 & 10 & 16 & 14 & 6 & 7 & 15 \\
\hline V & Fabaceae & 4 & 2 & 3 & 4 & 2 & - & 1 \\
\hline II & Caprifoliaceae & 7 & 7 & 8 & 11 & 7 & 6 & 8 \\
\hline IX & Rosaceae & 1 & 2 & 2 & 7 & - & - & - \\
\hline$X V$ & Caryophyllaceae & 1 & 1 & 1 & 1 & - & - & - \\
\hline XIV & Amaranthaceae & - & 2 & 3 & - & 3 & 1 & 2 \\
\hline IV & Polygonaceae & 1 & 3 & 4 & 3 & 2 & 2 & 4 \\
\hline VII & Apiaceae & 2 & 1 & 2 & 3 & - & - & 2 \\
\hline III & Brassicaceae & 2 & 3 & 5 & 4 & 1 & 2 & 5 \\
\hline VI & Sapindaceae & 3 & 3 & 3 & 3 & - & - & 2 \\
\hline$X V$ & Fagaceae & 1 & 1 & 1 & 1 & - & - & - \\
\hline XII & Ranunculaceae & 1 & 1 & 1 & 1 & - & 1 & 1 \\
\hline$X I$ & Lamiaceae & - & 2 & 3 & 3 & - & - & 1 \\
\hline$X V$ & Scrophulariaceae & 1 & 1 & 1 & 1 & - & - & - \\
\hline$x$ & Plantaginaceae & 2 & 2 & 2 & 2 & - & - & - \\
\hline XIII & Ulmaceae & 1 & 1 & 1 & 1 & - & - & 1 \\
\hline XVI & Other & & & & & & & \\
\hline
\end{tabular}

Comments: NLG - natural landscape features where grassy; NLW - natural landscape features where woody; R - ruderal landscape; OL - operating landfill; RL - reclaimed landfill. Comments here and in Table 4

Примітки: NLG - натуральний ландшафт, де переважає трав'яниста рослинність; NLW - натуральний ландшафт, де переважають дерева; R - рудеральний ландшафт; OL - епіцентр функціонування полігону (складування відходів); RL - рекультивований полігон. Примітки тут і в табл. 4

Table 4. Similarity of zones of Rohan and Derhachiv landfills

Таблиця 4. Подібність зон Роганського та Дергачівського полігонів

\begin{tabular}{c|c|c|c|c|c|c|c|c}
\hline $\begin{array}{c}\text { Zones of } \\
\text { landfills }\end{array}$ & NLW & NLG & R & OL & RL & NLW & NLG & R \\
\hline NLW & - & - & 0.18 & 0.35 & 0.40 & - & 0.41 & 0.59 \\
NLG & - & - & - & - & - & 0.41 & - & 0.63 \\
R & 0.18 & - & - & 0.48 & 0.32 & 0.59 & 0.63 & - \\
OL & 0.35 & - & 0.48 & - & 0.29 & - & - & - \\
RL & 0.40 & - & 0.32 & 0.29 & - & - & - & - \\
\hline \multicolumn{8}{l}{} \\
\hline
\end{tabular}

ISSN 1996-4536 (print) • ISSN 2311-0783 (on-line) • Біологічні Студії / Studia Biologica • 2020 • Том 14/№ 4 • С. 23-34 
From the data presented in Table 4, one can draw the following conclusions: research areas of Rohan landfill are characterized by significant similarity with $\mathrm{Cj}$ values from 0.75 to 0.59 points, indicating a high degree of vegetation similarity in the studied areas of the landfill; the flora throughout the landfill is rather homogeneous. In contrast, the studied areas of Derhachiv landfill are very heterogeneous and differ a lot in plant species composition ( $C j$ varying from 0.18 to 0.48 ). The similarity coefficient $C j$ calculated for two landfills is 0.11 . It illustrates a significant difference in the composition of flora, which is due to considerable differences in the formation of landfill ecosystems the age of landfills, specificity of land lying and usage, landscape historical background and floral genesis characteristic of Kharkiv region. However, the patterns in the vegetation formation of the disturbed landscapes can be traced quite clearly - a significant dismemberment of vegetation, abundance of ruderants in flora, peculiarities of flora formation in certain functional areas of landfills, etc.

Landfills are characterized by high temperatures, toxic dust deposition, biogas formation (due to garbage decomposition), soil contamination with toxicants [20]. In this regard, the spread and mass growth of eurytopic ruderal plant species (Ambrosia artemisiifolia (L., 1753), Urtica dioica (L., 1753), Artemisia vulgaris (L. 1753), etc.), malignant weeds (Impatiens parviflora (DC., 1824), Calamagrostis epigejos (L.) (Roth, 1788), Avena fatua (L., 1753) and dangerous invasive species (Acer negundo (L., 1753)) were observed at Kharkiv landfills. The presence of Cirsium vulgare (Savi) Ten. 1835), Plantago major (L., 1753) and Agropyron repens indicates that Landfills terrains are compacted, weakly acidic or acidic [19].

Lepidium Densiflorum (Schrad., 1832) — an adventitious plant, which is not typical for the study area and Inula Helenium (L., 1753), which is under protection in Kharkiv region, were interesting floristic finds on the territory of Derhachiv landfill [13].

The study recorded an increasing presence of agricultural plants in the landfills that are widely used by humans (fruit and cultivated plants), as well as a small number of ornamental plant species, which, probably due to ornithochoria, found an atypical place of growth and adapted to it (Solidago canadensis (L., 1753), (a typical weed, widespread in the region), Fragaria vesca (L., 1753), Triticum durum (L. (1753), etc.). Some introduced species were registered on the territories of the landfills ( $O L$ and $R L$ zones): Helianthus Annuus (L., 1753) and Triticum Durum. The study revealed an interesting fact about the phenological features of these species: the growing season significantly outstripped that of the plants growing under normal conditions. A similar fact was recorded in other scientific studies. This is due to an increased temperature regime in the active storage areas of the landfill, which are formed as a result of the humification process. Unfortunately, the proportion of phytomeliorants is extremely small (2.2\%), even smaller than the part of poisonous $(2.7 \%)$ and wild $(6.9 \%)$ species. To characterize the succession degree, a cenomorphic analysis of vegetation was performed (Table 5) [23]. Some species are transitional. For example, stepant-pratant (StPr) is a meadow species that can grow in steppe conditions.

It was established that the species that are represented in the vegetation of Kharkiv landfills cover all types of cenomorphs. The leading type of cenomorph for the landfills flora is ruderal species $(\mathrm{Ru})$, which is due to the significantly transformed landscapes in the active areas of landfill functioning where a secondary vegetation cover begins to form. A significant number of species are characteristic representatives of the forest (Sil), meadow (Pr) and steppe (St) plants. Such vegetation is typical of beam landscapes, in

ISSN 1996-4536 (print) • ISSN 2311-0783 (on-line) • Біологічні Студії / Studia Biologica • 2020 • Том 14/№ 4 • С. 23-34 
which landfills are laid according to standards. There are significantly fewer species of swamp (Pal), sand (Ps) and rock plants (Ptr). Thus, we can assume the existence of specific factors of the formation of such vegetation cover, whereby plants can be introduced due to ornithochoria, deflation, and surface runoff. Halophytes (Hal) and aquatic (Aq) species are the least abundant due to the atypical living conditions for such species, whereby soils are almost absent, highly degraded, poorly moistened and compressed.

\section{Table 5. Species of Derhachiv and Rohan landfills by cenomorphs}

Таблиця 5.Види за ценоморфами Дергачівського та Роганського полігонів

\begin{tabular}{c|c|c|c|c|c|c|c|c|c|}
\hline St & Sil & Pr & Pal & Ps & Hal & Ptr & Aq & Ru \\
\hline 28 & 42 & 34 & 6 & 5 & 1 & 3 & 1 & 57 \\
\hline
\end{tabular}

Comments: forest species - silvants (Sil); steppe species - stepants (St); meadow species - protanty (Pr); wetland species - paludants (Pal); plants of saline soils - halophytes (Hal); weeds - ruderants $(\mathrm{Ru})$

Примітки: лісові види - сільванти (Sil); степові види - степанти (St), лучні види - пратанти (Pr); болотні види - палюданти (Pal); рослини засолених ґрунтів - галофіти (Hal); бур'яни - рудеранти (Ru)

\section{CONCLUSIONS}

Vegetation cover of landfills is represented by at least 117 plant species. The plant species composition is dominated by herbaceous and perennial species, which indicates the processes of secondary succession in the formation of vegetation cover. The plant species of the studied landfills were classified according to their practical use. It was establisheded that a significant proportion of the species are weeds, medicinal, or food plants. On the other hand, there is an extremely small number of phytomeliorants that are essential for the territories of devastated landscapes; this indicates the low potential for restoration of natural landscapes.

The territories of the landfills were significantly dismembered in the process of exploitation, therefore, the vegetation of different areas is different. The vegetation in the areas of active transportation and unloading of waste $(\mathrm{OL})$ is represented by single ruderants, which indicates a high degree of territory damage, lack of fertile soil and primary succession signs. RL zones have a greater diversity of species, the leading families are Asteraceae and Caprifoliaceae, which in general are dominant families for both landfills. There is a tendency for secondary succession in these areas; ruderants are gradually being replaced by cultivated plants (ornithochorns from adjacent agrocenoses), perennials and shrubs. Similar trends are noticeable in the area of Derhachiv landfill, where the vegetation restoration has taken place for 20 years after reclamation. The NLW and NLG zones of both landfills were the most numerous by plant species. These territories are exposed to the least impact among other areas, and are formed independently. There is a significant dominance of perennials over ruderants and annuals, which indicates the potential for restoration of the natural landscape.

The regularities of vegetation formation on the territories of landfills have been determined, they include: a significant distribution of ruderal species in response to soil damage and a strong anthropogenic impact on the landscape; the presence of aboriginal plants, typical of the territories where landfills are laid; the invasion of species from

ISSN 1996-4536 (print) • ISSN 2311-0783 (on-line) • Біологічні Студії / Studia Biologica • 2020 • Том 14/№ 4 • С. 23-34 
adjacent areas as a result of transmission by abiotic factors and from other areas as a result of transmission by birds.

\section{ACKNOWLEDGEMENTS}

We are grateful to Yu. G. Gamula, Assoc. Prof., Ph.D., Head of the Department of Botany and Plant Ecology, V. N. Karazin Kharkiv National University and Yu. V. Bengus, senior lecturer at the Department of Botany of H.S. Skovoroda Kharkiv National Pedagogical University for their help in species identification and improvements to the manuscript.

\section{COMPLIANCE WITH ETHICAL STANDARDS}

Conflict of Interest: The authors declare that the research was conducted in the absence of any commercial or financial relationships that could be construed as a potential conflict of interest.

Animal Rights: This article does not contain any studies with animal subjects performed by the any of the authors.

1. Alekseenko V.A., Alekseenko L.P. Geochemical barriers. Moscow: Logos, 2003. 144 p. (In Russian)

Google Scholar

2. Andrienko T.L., Peregrym M.M. Official lists of regional rare plants of administrative territories of Ukraine (reference book). Kyiv: Alterpress, 2012. 148 p. (In Ukrainian)

Google Scholar

3. Alekhin V.V., Syreyshchikov D.P. Methods of field botanical research. Vologda: Severnyi pechatnik, 1926. 189 p. (In Russian)

4. Bilyk G.S. Ecological and coenotic features of vegetation cover of solid waste landfills on the territory of Lviv region. Scientific Principles of Biodiversity Conservation, 2011; 2(9), 1 : 33-50. (In Ukrainian)

Google Scholar

5. de Medeiros Engelmann P., dos Santos V.H.J.M., Barbieri C.B., Augustin A.H., Ketzer J.M.M., Rodrigues L.F. Environmental monitoring of a landfill area through the application of carbon stable isotopes, chemical parameters and multivariate analysis. Waste Management, 2018; 76: 591-605.

Crossref $\bullet$ PubMed $\bullet$ Google Scholar

6. Dobrochaeva D.N., Kotov M.I., Prokudin Yu.N. et al. The determinant of higher plants of Ukraine. Kiev: Naukova Dumka, 1987. 548 p. (In Russian)

Google Scholar

7. Evremenko N.S. Features of ruderal vegetation of territorial zones of Kryvyi Rih. Synanthropization of vegetation of Ukraine: III All-Ukrainian. Science. Conf., September 26-27, 2019, Kyiv. Collection of sciences. articles. Kyiv: Nash Format, 2019. P. 64-68. (In Ukrainian) Google Scholar

8. Glibovytska N. Environmental sustainability and phytomelioration suitability of woody plants in urban ecosystems. The Journal of V. N. Karazin Kharkiv National University. Series "Biology", 2017; 28: 12-21.

Google Scholar

9. Gurina I.V., Shchirenko A.I., Rogozina Y.S. The monitoring results of the second recultivated ash dump section of Novocherkassk SDP (state district power station). Scientific Journal of Russian RDI of Melioration Problems, 2016; 4(24): 55-69. (In Russian) Google Scholar

ISSN 1996-4536 (print) • ISSN 2311-0783 (on-line) • Біологічні Студії / Studia Biologica • 2020 • Том 14/№ 4 • С. 23-34 
10. Kharytonov M., Babenko M., Martynova N., Klimkina I., Heilmeier H. Testing of phytomeliorated dark - gray schist clay profile with miscanthus. Applied Biotechnology in Mining: Proceedings of the International Conference (Dnipro, April 25-27, 2018). Dnipro: National Technical University "Dnipro Polytechnic", 2018. P. 30.

Google Scholar

11. Leontyev D.V. Floristic analysis in mycology. Kharkiv: Osnova, 2007.160 p. (In Ukrainian) Google Scholar

12. Lutsevich A.A. Selection of flora of forest belts for reclamation of municipal solid waste landfills. Forestry Engineering Journal, 2015; 4(4): 21-25. (In Russian) Crossref • Google Scholar

13. Mazhaisky Yu.F. Restoration of lands contaminated with heavy metals. Melioration and Water Management, 2001; (2): 34-36. (In Russian)

Google Scholar

14. Petruk V.G., Vasilkivskij I.V., Ishchenko V.A., Petruk R.V. Management and disposal of wastes. Part 3. Solid household wastes landfills. Vinnytsia: VNTU, 2013. 139 p. (In Ukrainian) Google Scholar

15. Popovich V.V. Phytomeliorative recovery in reduction of multi-element anomalies' influence of devastated landscapes. Biological Bulletin of Bogdan Chmelnitskiy Melitopol State Pedagogical University, 2016; 6(1): 94-114.

Crossref $\bullet$ Google Scholar

16. Popovych V. Phytomelioration as a factor decommissioning landfills. Bulletin of Lviv State University of Life Safety, 2015; 11: 126-130. (In Ukrainian) Google Scholar

17. Prysedsky Yu.G., Lykholat Yu.V. Adaptation of plants to anthropogenic factors. Vinnytsia: Dnipro, 2017. 98 p. (In Ukrainian)

Google Scholar

18. Ramos-Arcos S.A., López-Martínez S., Lagunas Rivera S., González-Mondragón E.G., de la Cruz Leyva M.C., Velázquez-Martínez J.R. Phytoremediation of landfill leachate using vetiver (Chrysopogon zizanioides) and cattail (Typha latifolia). Applied Ecology and Environmental Research, 2019; 17(2): 2619-2630.

Crossref $\bullet$ Google Scholar

19. Samoilyk M.S., Molchanova A.V. Ecological aspects of influence of solid domestic wastes on the environment. Filtrate. Bulletin of Poltava State Agrarian Academy, 2017; 1-2: 88-91. (In Ukrainian) Google Scholar

20. Serebryakov I.G. The main directions in the evolution of life forms in angiosperms. Bull. of Moskow Society of exp. Nature, dep. biology, 1955; 60(3): 71-91. (In Russian) Google Scholar

21. Solid waste landfills. Basic design provisions 2005. URL: https://www.minregion.gov.ua/wp-content/uploads/2017/03/DBN-V.2.4-2-2005.pdf

22. Solomakha V.A., Kostyliov O.V., Sheliag-Sosonko Yu.R. Synanthropic vegetation of Ukraine. Kyiv: Naukova Dumka, 1992. 250 p. (In Ukrainian) Google Scholar

23. Tarasov V.V. Flora of the Dnipropetrovsk and Zaporizhya regions. Vascular plants with their biology-ecological characteristic. Dnipropetrovsk: Lira, 2012. 296 p. (In Ukrainian) Google Scholar

24. Titova M. Filter plants and fungi accumulators. Phyto-purification secrets. Online Journal "Givoy Les". (In Russian) URL: https://givoyles.ru/articles/lyudi-i-derevya/rasteniya-filtry-sekrety/

25. Varnavskaya I.V. Analysis of the conditions of formation and composition of wastewater of solid waste landfills. Ecology and Industry, 2008; 1: 39-43. (In Russian) Google Scholar

ISSN 1996-4536 (print) • ISSN 2311-0783 (on-line) • Біологічні Студії / Studia Biologica • 2020 • Том 14/№ 4 • С. 23-34 
26. Vaverková M.D., Winkler J., Adamcová D., Radziemska M., Uldrijan D., Zloch J. Municipal solid waste landfill - vegetation succession in an area transformed by human impact. Ecological Engineering, 2019; 129: 109-114.

Crossref $\bullet$ Google Scholar

27. http://www.mkpv.com.ua

\title{
АНАЛІЗ РОСЛИННОГО ПОКРИВУ ПОЛІГОНІВ ТВЕРДИХ ПОБУТОВИХ ВІДХОДІВ ХАРКІВЩИНИ
}

\author{
Я. Ю. Дементєєва*, С. В Асєєва, Л. Ю. Андрусенко, А. Б. Чаплигіна \\ Харківський національний педагогічний університет імені Г. С. Сковороди \\ вул. Алчевських, 29, Харків 61002, Україна \\ *Кореспондуючий автор e-mail: dementeeva.y@gmail.com
}

Вступ. Визначення видового різноманіття рослин на територіях полігонів твердих побутових відходів проведено з метою виділення закономірностей формування рослинного покриву й екологічної оцінки стану техноценозу. Дослідження видового різноманіття рослин здійснено на територіях Дергачівського та Роганського полігонів твердих побутових відходів у місті Харкові.

Матеріали та методи. Для обчислення видів використано метод лінійних маршрутів і пробних площ. Ступінь покриття знайдено методом Друде. Міру схожості визначено за допомогою розрахунку коефіцієнта Жаккара. Рослини систематизовано за видами, життєвими формами, тривалістю життя, типами ценоморф.

Результати й обговорення. На полігонах твердих побутових відходів міста Харкова зафріксовано всього 117 видів. На Роганському полігоні твердих побутових відходів і прилеглих до нього територіях рослинний покрив представлений 92 видами, на Дергачівському - 93 видами. Через нерівномірне розміщення рослинності на територіях виділено зони полігонів за специфікою рослинного покриву (4 для Дергачівського та 3 зони для Роганського полігонів). Найбільш виражена видова різноманітність рослин на Дергачівському полігоні у зоні натурального ландшафту $(44,0$ \%), на Роганському полігоні - у зоні рудерального ландшафту $(38,4$ \%). Виконано поділ отриманих даних за складом рослин і визначено умови існування. За життєвими фоормами на Дергачівському та Роганському полігонах домінантні трав'янисті рослини - 83,8 \% і 85,8 \% відповідно. За тривалістю життя переважають багаторічні рослини - 53,8 \% і 52,2 \%. Рослини полігонів за своїм практичним використанням - лікарські (18,6\%), харчові $(11,1 \%)$, медоноси $(10,8 \%)$, найменше рослин фрітомеліорантів (2,2 \%). Домінуючими родинами на обох полігонах $\epsilon$ Айстрові - 24,6 \% і Тонконогові - 13 \%. Коефріцієнти подібності Жаккара мали показники від 0,18 у найменш схожих між собою зонах до 0,75 у подібних зонах. Cj, розрахований для двох полігонів, дорівнює 0,11. Рослини систематизовано за ценоморфічною приналежністю. Провідний тип ценоморф для фрлори полігонів рудеральні види (Ru), також значну частку займають види, характерні для лісових рослин (Sil), лучних (Pr) і степових (St).

Висновки. Для територій складування твердих побутових відходів характерний високий ступінь трансформованості, що яскраво проявляється у формуванні рослинного покриву. Суттєва відмінність між рослинним покривом територій полігонів $(C j=0,11)$ пояснюється специфікою техногенезу досліджених екосистем,

ISSN 1996-4536 (print) • ISSN 2311-0783 (on-line) • Біологічні Студії / Studia Biologica • 2020 • Том 14/№ 4 • С. 23-34 
історичними ландшафтними та передумовами формування рослинного покриву. Природний трав'янистий рослинний покрив на полігонах замінюється рудеральним та чагарниковим, що вказує на складні умови існування для культурних рослин та сукцесійні процеси. Визначено, що рослинний покрив на територіях формується за трьома основними чинниками - історично характерні угруповання, які у відповідь на сильні порушення замінюються рудерантами в процесі сукцесії та деякі не притаманні види, заносяться біотичними чи абіотичними чинниками.

Ключові слова: рослинний покрив, Дергачівський полігон твердих побутових відходів, Роганський полігон твердих побутових відходів, трансформовані ландшафти, ценоморфічна приналежність 